\section{ПРОБЛЕМНЫЕ АСПЕКТЫ ПРАВОВОГО РЕГУЛИРОВАНИЯ СУРРОГАТНОГО МАТЕРИНСТВА}

\begin{abstract}
Аннотация:
Применение вспомогательных репродуктивных технологий не всегда влечет своевременное правовое регулирование отношений, возникающих в ходе использования методов лечения бесплодия Одним из таких методов является суррогатное материнство. Актуальность теоретического осмысления проблем нормативного обеспечения указанного вида материнства обусловлена увеличением спроса на его применение. Неполнота или отсутствие норм, регулирующих рассматриваемые отношения, нежелание законодателя своевременно реагировать на пробелы в законодательстве порождают трудности, с которыми вынуждены сталкиваться генетические родители и суррогатная мать. Автор приходит к выводу, что актуализация законодательства иелесообразна после изменения подхода государства к пониманию суррогатного материнства, а именно признания родительства за теми, кто лечит бесплодие. Спорность точек зрения по указанному вопросу может быть разрешена посредством устранения пробельности законодательства.
\end{abstract}

Ключевые слова:

суррогатное материнство, генетические родители, ребенок, вспомогательные репродуктивные технологии, правовое регулирование, семейное право.
THE PROBLEMATIC ASPECTS OF LEGAL REGULATION OF SURROGACY

\begin{abstract}
Summary:
The application of assisted reproductive technology is not always accompanied by legal regulation in due time during the use of methods of infertility treatment. One of such methods is surrogacy. The theoretical understanding of the legal support problems in relation to this kind of motherhood is relevant due to the increased demand for its application. Inadequacy or lack of regulation rules, as well as the reluctance of the legislator to fill the legal gaps pose challenges faced by the genetic parents and the surrogate mother. The author concludes that updating the legislation is appropriate after changing the government's approach to understanding surrogacy, namely the recognition of parenthood for people under infertility treatment. The controversial viewpoints on this issue can be resolved by filling the legal gap.
\end{abstract}

Keywords: surrogacy, genetic parents, child, assisted reproductive technology, legal regulation, family law.

Востребованность применения вспомогательных репродуктивных технологий в России обусловлена ухудшением репродуктивного здоровья женщин. Расширение объемов лечения бесплодия обозначено в качестве одной из задач государственной семейной политики в Российской Федерации, утвержденной распоряжением Правительства РФ от 25 августа 2014 г. № 1618-р (далее - Концепция государственной семейной политики РФ).

Одним из методов вспомогательных репродуктивных технологий является суррогатное материнство, спорность понимания и существования которого обозначена в науке и практике различных государств. Деликатное и противоречивое отношение к использованию указанного метода связано с духовными, этическими, медицинскими и правовыми факторами. Наличие законодательных пробелов, судебной практики не препятствует возрастанию спроса и материального интереса к суррогатному материнству. Обстоятельствами, предопределившими такой феномен, являются увеличение уровня бесплодия, ухудшение экономического положения в стране, запреты и ограничения национальных законодательств зарубежных стран. При этом последнее обстоятельство породило практику международной торговли в сфере суррогатного материнства [1].

Анализ применения суррогатного материнства в зарубежных странах свидетельствует о том, что проблемы в рассматриваемой сфере порождены категоричной позицией стран по этому вопросу или несвоевременным адекватным правовым регулированием. К примеру, в 2002 г. Верховным судом Индии было легализовано коммерческое суррогатное материнство в целях стимулирования медицинского туризма. Индия хотела создать себе репутацию международного суррогатного материка Мекки, предоставляя качественную медицинскую помощь по низкой цене и обеспечивая наиболее полную юридическую защиту для предполагаемых родителей. Растущий спрос на суррогатное материнство в Индии вызвал проблемы, в том числе проблемы прав ребенка [2, р. 129]. 
После того как в 2013 г. в Индии установили запрет на доступ к суррогатному материнству неженатым и однополым парам, одиноким людям, популярным местом стал Таиланд.

До недавнего времени в Таиланде отсутствовали законы, регулирующие суррогатное материнство. Потребность в законодательстве получила широкое признание, когда в фреврале 2010 г. полиция арестовала тайваньское посредническое агентство под названием Baby 101, расположенное в Бангкоке. Оно держало взаперти 15 вьетнамских женщин, которые были проданы, чтобы рожать детей иностранным клиентам. В 2010 г. приняли закон, запрещающий коммерческое суррогатное материнство, который был одобрен тайским правительством, но оставался нерассмотренным национальной ассамблеей. Поэтому коммерческое суррогатное материнство оставалось юридически неоднозначным, что позволило продолжить коммерциализацию репродукции третьей стороной. После прецедента по возвращению гражданином Австралии одного из близнецов суррогатной матери в феврале 2015 г. издали закон, согласно которому только женатые тайские пары или пары с одним тайским партнером, которые поженились не менее трех лет назад, могут искать суррогатную мать на альтруистической основе, а коммерческое суррогатное материнство полностью запретили, за него предусмотрели наказание до 10 лет тюрьмы [3, р. 11, 12].

Полагаем, что практика и опыт Таиланда по своевременному и соответствующему законодательному регулированию суррогатного материнства могут быть восприняты другими странами, в том числе Россией.

Великобритания не запрещает суррогатное материнство, но и не позволяет ему развиваться неограниченно. Оно разрешается, при условии что согласовано и возможна оплата только разумных расходов, т. е. коммерческая основа запрещена. Аналогичной позиции придерживается Австралия, где законодательство о суррогатном материнстве предусматривает наказание за коммерческое соглашение о суррогатном материнстве [4, p. 62, 66].

Масштабность использования метода суррогатного материнства требует особого внимания законодателя. Между тем правовое регулирование суррогатного материнства в России весьма поверхностно, о чем свидетельствует обширная судебная практика.

Недостаточность правового регулирования рассматриваемых отношений связана с отсутствием законодательно закрепленного понятия суррогатного материнства [5, с. 6]. Термин «суррогатное материнство» трактуется по-разному [6, с. 11], при этом основополагающим выступает вынашивание и рождение ребенка для потенциальных родителей. Подобный подход воплощен в п. 9 ст. 55 Федерального закона от 21 ноября 2011 г. № 323-Ф3 «Об основах охраны здоровья граждан в Российской Федерации» (далее - № 323-Ф3). В теории распространен термин «суррогатная мать». В то же время существует биологически более точное, но не вполне привычно звучащее словосочетание «гестационный курьер» [7, с. 167], которое употребляется Всемирной организацией здравоохранения (далее - ВОЗ). Согласно формулировке ВОЗ суррогатная мать не может быть одновременно донором яйцеклетки, родителями ребенка признаются те лица, чьи половые клетки использовались для оплодотворения. Аналогичное понимание содержится в п. 10 ст. 55 № 323-Ф3.

В силу п. 4 ст. 51 Семейного кодекса РФ (далее - СК РФ) потенциальные родители могут быть записаны родителями ребенка только с согласия женщины, родившей ребенка (суррогатной матери). Безапелляционное наличие обязательного согласия суррогатной матери не согласуется не только с сущностью самого термина, но и с его целевым назначением.

Правовая природа отношений между суррогатной матерью и потенциальными родителями предполагает обязательство женщины по вынашиванию и рождению ребенка не для себя, а для генетических родителей, а также наличие генетической связи между ребенком и лицами, ожидающими ребенка. Применение вспомогательных репродуктивных технологий, как правило, вызвано желанием иметь родного ребенка. В связи с этим закрепление в СК РФ зависимости возникновения прав родителей от волеизъявления суррогатной матери не соответствует законодательно установленному праву на отцовство и материнство, а также сути суррогатного материнства.

В науке выделяются различные взгляды на указанную проблему. Некоторые исследователи согласны с позицией государства, в соответствии с которой суррогатная мать вправе давать согласие на запись родителями ребенка тех лиц, которым она помогает. Остальные считают это нарушением прав генетических родителей.

По мнению А.Я. Ахмедова, в целях укрепления семьи интересы заказчиков подлежат большей защите, чем интересы суррогатной матери [8, с. 4]. Ю.А. Дронова отмечает, в связи с тем что репродуктивные технологии способствуют преодолению бесплодия, непонятно, почему необходимо защищать интересы суррогатной матери, сознательно решившейся на подобный шаг, притом что она может родить собственного ребенка естественным путем, а ребенок, рожденный ею, является ей генетически чужим [9]. 
Имеются противники суррогатного материнства, считающие его противоестественным и морально недопустимым, даже когда оно осуществляется на некоммерческой основе. Это объясняется тем, что оно травмирует как вынашивающую женщину, материнские чувства которой попираются, так и дитя, которое впоследствии может испытывать кризис самосознания [10].

А.Т. Боннер подчеркивает, что, несмотря на массу сложностей, институт искусственного оплодотворения уже прижился в России и, безусловно, будет развиваться и впредь [11, с. 187]. Указанный подход подтверждается задачами, обозначенными в Концепции государственной семейной политики РФ.

Возможность признания суррогатной матери в качестве родителя ребенка повлекла за собой неопределенность в употреблении термина «биологический родитель». В науке он применяется повсеместно в отношении как генетических родителей, так и матери, родившей ребенка.

Несовершенство законодательства содействует суррогатным матерям в злоупотреблении своим абсолютным правом на оставление ребенка у себя, на что указывает устоявшаяся судебная практика. Однако недавно Петербургским районным судом было рассмотрено дело, которое названо прецедентным ввиду того, что суд занял позицию генетических родителей [12]. Пленумом Верховного суда РФ принято постановление от 16 мая 2017 г. № 16 [13], в соответствии с которым отказ суррогатной матери передать ребенка родителям не может служить безусловным основанием для отказа в удовлетворении иска потенциальных родителей о признании их родителями ребенка и передаче им ребенка на воспитание. Вероятно, судебная практика подтолкнет законодателя к внесению изменений в СК РФ.

Важной правовой проблемой считается отсутствие необходимых требований к потенциальным родителям. Учитывая смысл и назначение применения суррогатного материнства, к такому методу прибегают лица, не имеющие возможности по медицинским показаниям иметь детей. Предполагается, что опыт родительства у них отсутствует. В целях формирования психологической готовности принять и воспитать ребенка предлагаем предусмотреть возможность посещения ими школ приемных родителей с учетом сохранения конфиденциальности.

Проблема незащищенности прав и законных интересов ребенка связана с отсутствием правовой регламентации указанной сферы [14, с. 4]. Пробельность законодательства не всегда может быть восполнена аналогией закона или аналогией права. В качестве примера можно привести гражданское дело по исковому заявлению гражданки к Управлению ЗАГС об обязании внести изменения в запись о рождении сына Л. [15].

Итак, вопросы применения вспомогательных репродуктивных технологий разрешаются на уровне практики, а также в судебных решениях. Спорность суждений относительно суррогатного материнства требует объективных изменений законодательного подхода к признанию родительства за теми, кто лечит бесплодие. Впоследствии видится целесообразным внести соответствующие изменения в законодательство. Полагаем, что практика и опыт некоторых стран по своевременному и адекватному законодательному регулированию указанной сферы могут быть восприняты Российской Федерацией.

\section{Ссылки:}

1. Базедов Ю. Право открытых обществ - частное и государственное регулирование международных отношений : общ. курс междунар. част. права / пер. с англ. Ю.М. Юмашева. М., 2016. 384 с.

2. Does Surrogacy Involve Making Families or Selling Babies? / V. Singh, P. Thakur, Byasdev, Anjum // International Journal of Healthcare Sciences. 2014. Vol. 2, iss. 1. April - September. P. 129-130.

3. Nilsson E. Merit Making, Money and Motherhood: Women's Experiences of Commercial Surrogacy in Thailand : master thesis in gender studies. Uppsala, 2015.

4. Ben-Nun L. Surrogate Motherhood. Hagar and Sarah. Medical Research in Biblical Times from the Viewpoint of Contemporary Perspective [Электронный ресурc]. Beer-Sheva, 2014. URL: https://www.researchgate.net/profile/Liubov_Ben-Noun_nun/publication/281823435 SURROGATE MOTHERHOOD Hagar and Sarah/links/55f9923308aeafc8ac264baa/SURROḠATEMOTHERHOOD-Hagar-and-Sarah.pdf (дата обращения: 14.07.2017).

5. Борисова Т.Е. Суррогатное материнство в Российской Федерации: проблемы теории и практики : монография. М., 2014. 144 C.

6. Журавлева Е.М. Проблемы наследования насцитурусом в рамках действия договора суррогатного материнства // Наследственное право. 2013. № 1. С. 10-13.

7. Боннер А.Т. Искусственное оплодотворение: достижения и просчеты современной медицины и человеческие драмы // Закон. 2015. № 8. С. 164-183.

8. Ахмедов А.Я. Поименованные и непоименованные договоры, направленные на укрепление семьи // Семейное и жилищное право. 2016. № 6. С. 4-7.

9. Дронова Ю.А. Что нужно знать о суррогатном материнстве. М., 2007. 112 с.

10. Биомедицинское право в России и за рубежом : монография / Г.Б. Романовский, Н.Н. Тарусина, А.А. Мохов и др. М., 2015. $368 \mathrm{c}$

11. Боннер А.Т. Искусственное оплодотворение: достижения и просчеты современной медицины и человеческие драмы // Закон. 2015. № 9. С. 168-187. 
12. Петербургский суд обязал суррогатную мать отдать двойню биологическим родителям [Электронный pecypc]. URL: http://mama66.ru/news/peterburgskijj-sud-obyazal-surrogatnuyu-mat-otdat-dvojjnyu-biologicheskim-roditelyam (дата обращения: 14.05.2017).

13. О применении судами законодательства при рассмотрении дел, связанных с установлением происхождения детей [Электронный ресурс] : постановление Пленума Верховного суда Российской Федерации от 16 мая 2017 г. № 16. URL: https://rg.ru/2017/05/24/detiproishozhd-dok.html (дата обращения: 14.05.2017).

14. Алборов С.В. К некоторым вопросам обеспечения интересов ребенка при применении технологии суррогатного материнства // Семейное и жилищное право. 2016. № 5. С. 4-7.

15. Решение Тверского районного суда города Москвы от 7 февр. 2013 г. по делу № 2-640/2013 [Электронный ресурс]. URL: http://sudact.ru/regular/doc/tJL1 piMkTIUZ/ (дата обращения: 14.05.2017).

\section{References:}

Akhmedov, AYa 2016, 'Defined and non-defined contracts aimed at strengthening the family', Semeynoye i zhilishchnoye pravo, no. 6, pp. 4-7, (in Russian).

Alborov, SV 2016, 'Serving the interests of the child when applying surrogate technology', Semeynoye i zhilishchnoye pravo, no. 5, pp. 4-7, (in Russian).

Basedow, J \& Yumashev, YuM (transl.) 2016, The law of open societies - private ordering and public regulation in the conflict of laws, Moscow, 384 p., (in Russian).

Ben-Nun, L 2014, Surrogate Motherhood. Hagar and Sarah. Medical Research in Biblical Times from the Viewpoint of Contemporary Perspective, Beer-Sheva, viewed 14 July 2017, <https://www.researchgate.net/profile/Liubov_Ben-Noun_nun/publication/281823435_SURROGATE_MOTHERHOOD_Hagar_and_Sarah/links/55f9923308aeafc8ac264baa/SURROGATE-MOTHERHOOD-Hagar-and-Sarah.pdf>.

Bonner, AT 2015a, 'Artificial insemination: achievements and miscalculations of modern medicine and human dramas', Zakon, no. 8, pp. 164-183, (in Russian).

Bonner, AT 2015b, 'Artificial insemination: achievements and miscalculations of modern medicine and human dramas', Zakon, no. 9, pp. 168-187, (in Russian). Russian).

Borisova, TE 2014, Surrogacy in the Russian Federation: theoretical and practical issues, monograph, Moscow, 144 p., (in

Dronova, YuA 2007, Everything you need to know about surrogacy, Moscow, 112 p., (in Russian).

Nilsson, E 2015, Merit Making, Money and Motherhood: Women's Experiences of Commercial Surrogacy in Thailand: master thesis in gender studies, Uppsala.

Romanovsky, GB, Tarusina, NN \& Mokhov, AA (et al.) 2015, Biomedical law in Russia and abroad, monograph, Moscow, 368 p., (in Russian).

Singh, V, Thakur, P, Byasdev \& Anjum, 2014, 'Does Surrogacy Involve Making Families or Selling Babies?', International Journal of Healthcare Sciences, vol. 2, iss. 1, April - September, pp. 129-130.

Zhuravleva, EM 2013, 'Problems of inheritance by nasciturus within the surrogacy contract', Nasledstvennoye pravo, no. 1, pp. 10-13, (in Russian). 